\title{
FEATURES OF IMPLEMENTATION OF THE COMPETENCE APPROACH TO THE STUDY OF CLINICAL ANATOMY IN MEDICAL SCHOOL
}

\author{
В. В. Уліщенко, В. Г. Черкасов, М. Р. Ігнатіщев \\ Національний медичний університет імені О. О. Богомольцяя
ОСОБЛИВОСТІ РЕАЛІЗАЦІЇ КОМПЕТЕНТНІСНОГО ПІДХОДУ ДО ВИВЧЕННЯ КЛІНІЧНОЇ АНАТОМІЇ У ВИЩОМУ МЕДИЧНОМУ НАВЧАЛЬНОМУ ЗАКЛАДІ

\begin{abstract}
The article analyzes the methodical problems of teaching the clinical anatomy in medical schools, discusses the peculiarities of the organization of competency-based training in the unity of classroom and independent work of students. Emphasis is placed on the existence of some discrepancy between the expectations and the learning outcomes, which is related to the students' insufficiently high educational motivation, not always appropriate application of methods and techniques by the teachers. High educational results are possible with the joint efforts of all subjects of education.

Interviews and questionnaires of students and teachers to identify reserves of improving the quality of knowledge (100 respondents) showed that the leading form of acquiring new knowledge is an interactive lecture. The perception of theoretical material depends on the structure, the visual richness of such lecture. The second place were given for practical work (models, albums, videos, etc.) and third - for independent work (solving anatomical problems, preparation of individual and group projects). Provided the students are internally motivated, the tasks are systematic and visible, these kinds of work will deepen knowledge and ability competencies (analyze, differentiate, organize). The authors' attention is focused on the application of such training methods as scribing, mnemonic schemes, compiling a descriptive story and more.
\end{abstract}

Key words: competence approach; competencies; anatomy; content visualization; scribing; mnemonic schemes; descriptive story.

Анотація. У статті проаналізовано методичні проблеми викладання клінічної анатомії у вищих медичних навчальних закладах, розглянуто особливості організації компетентнісно орієнтованого навчання в єдності аудиторної та самостійної роботи студентів. Зроблено акцент на існуванні певної невідповідності між очікуваннями та результатами навчання, що пов’язано 3 недостатньо високою навчальною мотивацією студентів, не завжди доцільним застосуванням методів і прийомів навчання викладачами. Високі освітні результати можливі за умови спільних зусиль усіх суб’єктів навчання.

Інтерв’ювання та анкетування студентів і викладачів на предмет виявлення резервів підвищення якості знань (100 респондентів) показали, що провідною формою набуття нових знань є інтерактивна лекція, від структурованості, проблемності, візуальної насиченості якої залежить сприйняття теоретичного матеріалу. Друге місце респонденти надали практичній роботі (муляжі, альбоми, відео тощо), а третє - самостійній роботі (розв’язання анатомічних задач, підготовка індивідуальних і групових проектів), що за умови внутрішньої вмотивованості студентів, системності та осяжності завдань сприятиме поглибленню набутих знаннєвих та уміннєвих компетенцій (аналізувати, диференціювати, систематизувати). Увага авторів зосереджується на застосуванні таких прийомів навчання, як скрайбінг, мнемосхеми, складання описової розповіді тощо.

Ключові слова: компетентнісний підхід; компетенції; анатомія; візуалізація контенту; скрайбінг; мнемосхеми; описова розповідь.

Introduction. The IFOM (International Fundamentals of Medicine) exam, launched in Ukraine, made it possible to make visible the characteristics of medical education development in Ukraine. Analytical mate-

(c) V. V. Ulishchenko, V. H. Cherkasov, M. R. Ihnatishchev rial "International Exam in the Fundamentals of Medicine (IFOM 2019: Expert Assessment" recognized the "correlation between the number of correct student responses and the proactive position of universities to adapt plans and programs to international standards” 
[6]. The average success rate of future physicians, according to IFOM, was only $30.2 \%$, while in Europe and America it does not fall below $50 \%$. The low rate in our students is associated with both the existing gaps in knowledge and the urgent need to update the curricula and training programs for future physicians at medical universities. In this perspective, the active introduction of a competency-based approach in the study of key subjects of medical education, in particular anatomy, becomes particularly relevant.

Considering that the competence approach today occupied a leading position in the world educational practice, in particular in medicine, its implementation on the example of studying a particular fundamental subject does not always show the expected results in the form of competencies (knowledge, skills, values) as indicated in the preface to the training programs.

The discrepancy between expectations and learning outcomes requires careful thinking on the forms, methods and techniques commonly used in the practice of training a future physician, synthesis acquired information and formulating suggestions for improving the quality of mastering basic theoretical subjects. It is the interrelation and interdependence of the methodological component with the problems of teaching (lectures, practical trainings, seminars, independent work of students) that needs constant attention, correction, which should affect the improvement of learning outcomes.

Mastering clinical anatomy provides the qualitative foundations for shaping the future doctor's professional competence and involves not only studying the location and structure of a particular organ, but also understanding the complex interconnection of organs into holistic systems of a healthy and sick person, the interaction of these systems within a holistic organism. The soundness of knowledge in clinically oriented (descriptive in nature) human anatomy is like a litmus test, which signals the student's willingness to understand the intricacies of pathological anatomy, physiology, clinical subjects. Of course, much depends on the persistence, motivation of work of future physicians, but the responsibility for the quality of mastering the educational material also lies in the plane of methodical literacy of teachers, who must take care of the choice of optimal methods, techniques and forms of classroom or extra-curricular work, meeting the cognitive interests and needs of young people.

The aim - to analyze the characteristics of the implementation of anatomy's competency-based teaching in higher medical education (foreign and domestic), to study the effectiveness of teaching methods, techniques and forms of work in the aspect of forming knowledge, skills and value competences, to outline vectors for further methodological exploration.

During the research, theoretical (critical analysis and synthesis of research results of domestic and foreign scientists) and empirical (interviewing, questioning students and teachers) methods, methods of mathematical statistics were used.

Theoretical framework. In domestic and foreign methods of teaching anatomy the work on the preparation of a corpse was considered the most perfect and is considered so today, because this is the way students acquire knowledge and practical skills to analyze organs and systems of the organism in their interdependence $[1-4,7,8]$. In conditions of reduction of academic hours, observance of requirements of medical ethics, practice of work with cadaveric material is replaced by visual teaching methods, which affected the quality of training of graduates and led to an increase in the number of medical errors [13]. D. Pronyaev emphasizes that with increasing prestige of popular science films in anatomy, exhibitions of works by Gunther von Hagens, increased the number of supporters of the study of human anatomy on charts, layouts, models, but acknowledges: “... only the student's direct contact with cadaveric material will ensure a proper level of learning” [8]. Patrick J. O’Byrne draws attention to the fact that large student groups, complicated curricula and lack of regular access to cadaveric material have a significant impact on the quality of academic achievement. In order to overcome the negative effects, he and his colleagues suggested, using Adobe Flash MX TM, to take high-quality digital photos on cadaveric material, to digitize illustrations of textbooks. The obtained images of the internal organs and their microstructures, due to their high quality, were suitable for the further development of interactive posters on human anatomy [12].

O. Gundarova, A. Kvatatshelia also recognize that the study of anatomy can't do without the work of students with cadaveric material in the autopsy room and the anatomy museum, because it is not necessary to violate the basic principle of the study of anatomy "anatemno - dissect" [2]. Scientists insist on the widespread use of the Internet, various visual training programs, which will help the teacher to increase the students' educational motivation, to activate their cognitive activity. With the qualitative and motivated independent (individual and group) work of students 
using various sources of information (lectures, textbook, exercise book, Internet, educational films and programs) and modern high-tech non-invasive or minimally invasive methods of clinical visualization of anatomical structures of a living person, the quality of mastering the subject is being improved.

O. Popov and co-authors insist on the necessity of active use in training of computer programs, educational films, museum exhibits, because, according to scientists, the best atlases cannot perfectly reproduce the peculiarities of the multilayered structure of the human body. Computer graphics "allow you to see the layered structure of human body systems in different angles, in layers, in sections and in different functional phases" [4]. A. Zhukov and co-authors draw attention to the need to improve the quality and quantity of visual aids on the structure of organs and systems of the human body. For this purpose students under the guidance of teachers recorded training videos on osteology and uploaded them to created YouTube channel. Oral explanation was accompanied by video material, which has many advantages over printing sources: "Other cortical analyzers are involved, lexical units are enhanced by visual images, the learning process is individualized, tension is reduced and adaptation to learning is increased" [3].

It is generally accepted that lectures, seminars, practicals and coursework are the leading forms of training and control. However, visualization (illustrations, photos, presentations, videos, high-quality bone material, etc.) is of particular importance for students to study educational material profoundly [6]. It is not uncommon to comment on the feasibility of using game technologies in anatomy training, which will promote self-development, student self-realization, will help to combine knowledge with skills, for example, by combining bones, modeling joint functions and giving it a complex characteristic [7].

The study of anatomy can not be monotonous, it must take into account all possible forms of training, activate different means of perception (audio, visual, kinesthetic) [11]. L. Udochkina emphasizes the importance of qualitatively prepared independent work of students, because in the general segment of hours it reaches $30 \%$ and cannot be limited exclusively to work with didactic materials and consultations of the teacher. The skills of independent work of first-year students are practically not formed, most students are not able to work with literature, to be proactive and self-organized. The lack of such skills, according to the researcher, is a serious drawback in mastering the fundamental bases of medicine. The teacher also gets an extra load - to teach the student to study both under the guidance of the mentor and without him. The effectiveness of independent work increases the involvement of students in work in the anatomical circle, the preparation of thematic conferences, the production of the visual aids [11]. M. Sapin holds a similar view. Only persistent independent work - a thorough study of every detail of the organ with the help of the visual aids, a textbook and an atlas (after each lecture session), as far as he is convicted, will contribute to the formation of qualitative knowledge and skills [9].

Analysis of scientific sources shows that at the present stage in the methodology of studying morphological subjects, particularly anatomy in medical universities there are several leading approaches - the use of visual aids to visualize the learned material (films, presentations, atlases, layouts, etc.) and mnemonic techniques (designing, self-coloring of images of anatomical structures in coloring books, etc.). It is the mnemonics that activate tactile sensations and, through the formation of associations (associative chains), improve the perception of complex theoretical material and its further identification.

In order to improve the medical component, increase students' motivation to study human anatomy, the Department of Descriptive and Clinical Anatomy of the O. Bohomolets Medical University has introduced techniques of mnemotechnics (mnemonic scheme, compilation of narrative story, etc.) into the teaching of the subject. For example, when studying the circulatory system, students are encouraged to select an appropriate photograph from X-ray examination, spirulography, endoscopic examinations with an image of the structure (section) of each organ for each organ marked on the mnemonic scheme. Of course, photographs (photocopies) must be of high quality, clear and not ambiguous, although the angles of the organ image may be different. The number of photographs (photocopies) should be greater in order for students to exercise the utmost attention in order to provide a complete answer, to demonstrate the formed ability to analyze, differentiate, synthesize anatomically essential information obtained after using clinical methods of the examination of living human.

Among the effective methods of training we should pay attention to the compilation of a detailed description of the body (part of it), which requires a clear understanding of structural, functional, topo- 
graphic features and may be possible only if subject has been thoroughly studied. Such a technique is not intended to reproduce the textbook unit, but involves the verbalization of the results of students' independent analytical and synthesizing work. It is usually performed after watching a video, working with an atlas, and so on. A large selection of videos is presented on the website of the Ministry of Health of Ukraine (https://moz.gov.ua) in the section "Sites, applications, video lectures: 7 useful online resources for physicians" and on the site https://anatom.ua/. We believe that each learning situation should have a logical conclusion, and therefore compiling a detailed description after watching the video and the images obtained through instrumental visualization, will help to organize the material which have been seen, heard, perceived and comprehended.

An important place in the process of studying human anatomy relates to scribing (from English Scribe - to make sketch), which is created with the help of programs Power Point, PowToon, GoAnimate, Sparkol VideoScribe. This training technique combines graphic illustration (visual series) with the revealing of theoretical material (educational topic) and allows to focus the attention of the students on key points of the report. It should be noted that scribing is recognized as one of the effective training methods on popular YouTube channels. Its effectiveness is evident during the presentation of new material by a teacher or during a student's presentation at a seminar. Thanks to the logic of graphic visualization, the students can better memorize the educational material, develop their observation and critical thinking. The methodical benefit in the study of anatomy was found in the following varieties of scribing:

- schematic (diagrams and drawings by hand),

- application (overlay of completed images on the prepared background),

- video scribing.

Those types of educational technique are chosen which will be more interesting, more effective. It depends on personal preferences, the formation of communication and information competences in all subjects of learning.

It is important that scribing improves students 'perceptions of new material during the lecture and helps them to think critically about students' answers, provided that certain important steps are clearly observed:

- determining the purpose, plan, content of the report;
- selection of visualization methods, sequence of reproduction of each content node;

- preparation of appropriate necessary things (markers, stickers, etc.);

- analysis of the correspondence between the video content and the theoretical material.

The key to high learning outcomes is student motivation, positive mood, minimizing the stress factor and the ability to self-realization through action (educational and scientific work). That is why one of the effective types of independent work is problematic tasks (performed in groups, individually or in pairs). For example, here are some of them.

Task 1. Compare the blood flow in the adult and the fetus, identify and explain the anatomical differences in the blood circulation pathways (Diagram 1, 2).

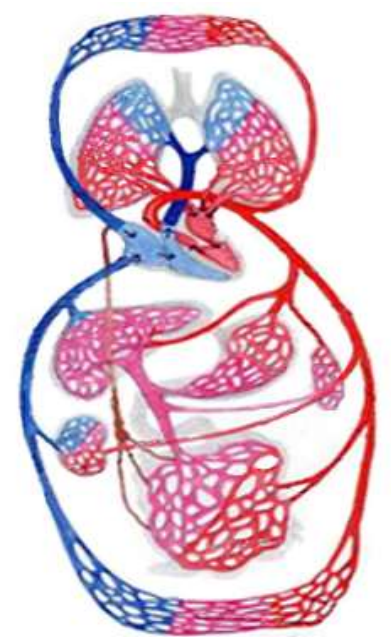

Diagram 1. The large and small circulation [14].

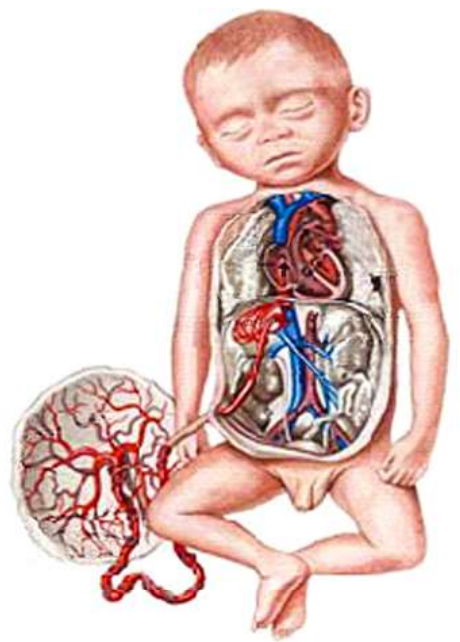

Diagram 2. The fetal circulation system [14].

Task 2. Find the anatomical differences of venous blood flow in the system of the portal hepatic vein and the vena cava. 


\section{Materials of International Scientific and Practical Conference \\ "PROFESSIONAL AND COMMUNICATION CULTURE OF THE FUTURE DOCTOR: LINGUISTIC, PEDAGOGICAL AND PHILOSOPHICAL ASPECTS”}

Problem solving requires students to revert to theoretical material, atlases, videos, and more. Such work develops persistence, logic, creativity, critical and systemic thinking, emphasizes the development of practical skills and promotes better acquisition of educational material.

In order to rank and identify the most effective for the acquisition of knowledge and the acquisition of appropriate skills, teaching methods and forms of work were interviewed 100 people (students 1-2 years of study and teachers). The respondents were asked to:

- to name an effective method of acquiring theoretical knowledge (perception of a new topic) and to determine the optimal set of options for its implementation;

- to name the effective method of acquisition of practical skills, to outline requirements for its implementation, improvement;

- determine the effective type of tasks for independent work.

On the first question, $98 \%$ of the "yes" were given for lectures provided the combination of problembased learning, interactivity, and use of visual range. $2 \%$ of respondents did not express their opinions. The second question showed that practical work in all its variants is absolutely necessary for the formation of practical skills (competences). $73 \%$ of respondents preferred group work during the class, and only $27 \%$ preferred to work independently. Among the

\section{List of literature}

1. Анатомія людини : у 3-х т. / [А. С. Головацький, В. Г. Черкасов, М. Р. Сапін та ін.] ; за ред. В. Г. Черкасова, А. С. Головацького. - Вінниця : Нова Книга, 2019. 1200 с. : іл.

2. Гундарова О. П. Система информационного обеспечения при изучении анатомии человека / О. П. Гундарова, А. Г. Кварацхелия // Анатомия и гистопатология. Приложение. - 2017. - № 5. - С. 14.

3. Жуков А. В. Инициация инновационного подхода в обучении анатомии человека / А. В. Жуков, С. Е. Байбаков, Г. Р. Агаджанян // Анатомия и гистопатология. Приложение. - 2017. - № 5. - С. 14-15.

4. Методика викладання топографічної анатомії у Одеському державному медичному університеті у сучасних умовах / О. Г. Попов, В. В. Десятський, О. Л. Кошельник [та ін.] // Світ медицини та біології. - 2009. Вип. 3. - С. 129-131.

5. Міжнародний іспит з основ медицини (IFOM) - 2019: оцінка експертів. - Режим доступу : https://moz.gov.ua/ article/news/mizhnarodnij-ispit-z-osnov-medicini-ifom--2019-ocinka-ekspertiv. most effective tasks for independent work (in view of the formation of knowledge and skills) were the preparation of reports using scribing, problem solving and working with atlases (coloring).

Despite the complexity and terminological saturation of the course of human anatomy, students recognized its importance for the further study of medicine, emphasized that diversification of methods and techniques of training helps to support motivation, promotes deeper learning of the theory and the acquisition of appropriate skills.

Conclusions and Prospects for Research. Traditional teaching methods and techniques (lectures, practicals and seminars) remain effective provided they are updated and brought closer to the interests of today's youth. The involvement of new methodological techniques will help to express theoretical and practical ideas, increase the educational motivation and professional interest in the study of a complex and extremely important for the future physician subject descriptive and clinical anatomy. It is important for the traditional and innovative complex to work successfully on the implementation of a competencybased training, to give impetus for the development of initiative, creativity, critical thinking.

It is important to research the ways of improving of the university lecture, which, in accordance with the requirements of the time, should be problem-based, interactive, with the involvement of student assistants.

6. Міськів В. А. Деякі аспекти викладання анатомії для студентів медичного коледжу / В. А. Міськів // Вісник проблем біології і медицини. - 2014. - Вип. 4, т. 2 (114). - C. 51-57.

7. Обухова 3. О. Викладання анатомії людини у вищій медичній школі: креативність як запорука якості знань / 3. О. Обухова. - Режим доступу : https://vseosvita.ua/library/ dopovid-na-zasidanni-predmetnoi-ciklovoi-metodicnoikomisii-prirodnico-naukovoi-pidgotovki-na-temu-vikladannaanatomii-ludini-u-visij-medicnij-skoli-k-180162.html.

8. Проняєв Д. В. Щодо методики викладання анатомії у вищих навчальних закладах / Д. В. Проняєв // Перспективи розвитку медичної науки і освіти : зб. тез доповідей Всеукр. наук.-метод. конф., присвяченої 25-річчю Медичного інституту Сумського державного університету (Суми, 16-17 листоп. 2017 р.). - Суми : СумДУ, 2017. - C. 61-62.

9. Сапин М. Р. Анатомия человека - базовая наука в медицинском образовании / М. Р. Сапин // Медицинское образование и профессиональное развитие. - 2011. № 2 (4). - С. 96-97. 


\section{Materials of International Scientific and Practical Conference \\ "PROFESSIONAL AND COMMUNICATION CULTURE OF THE FUTURE DOCTOR: LINGUISTIC, PEDAGOGICAL AND PHILOSOPHICAL ASPECTS”}

10. Сучасна організація педагогічного процесу на кафедрі анатомії людини / В. Г. Черкасов, А. С. Головацький, I. В. Дзевульська [та ін.] // Науковий вісник Ужгородського університету. Серія «Медицина». - 2011. - Вип. 2. C. 365-369. - Режим доступу : http://nbuv.gov.ua/UJRN/ UNUMED_2011_2_82.

11. Удочкина Л. А. Формирование компетентностного подхода в изучении анатомии человека / Л. А. Удочкина // Медицинский журнал Западного Казахстана. 2013. - № 3 (39). - С. 15-19.

\section{References}

1. Holovatskyi, A.S., Cherkasov, V.H., \& Sapin, M.R. (2019). Anatomiia liudyny u 3-kh tomakh [Human anatomy in 3 vol.]. Cherkasov, V.H., \& Holovatskyi, A.S. (Eds.). Vinnytsia: Nova Knyha [in Ukrainian].

2. Hundarova, O.P. (2017). Sistema informatsyonnogo obespecheniya pri izuchenii anatomii cheloveka. Prylozhenye [Information support system in the study of human anatomy]. Anatomiya i gistopatologiya - Anatomy and Histopathology, 5, 108 [in Russian].

3. Zhukov, A.V. (2017). Initsyatsiya innovatsyonnogo podkhoda $\mathrm{v}$ obuchenii anatomii cheloveka [Initiation of an innovative approach in teaching human anatomy]. Anatomiya i gistopatologiya - Anatomy and Gistopathology, 5, 108 [in Russian].

4. Popov, O.H. (2009). Metodyka vykladannia topohrafichnoi anatomii u Odeskomu derzhavnomu medychnomu universyteti u suchasnykh umovakh [Methods of teaching topographic anatomy at Odesa State Medical University in modern conditions]. Svit medytsyny ta biolohii - The World of Medicine and Biology, 3, 129-131 [in Ukrainian].

5. Mizhnarodnyi ispyt z osnov medytsyny (IFOM) - 2019: otsinka ekspertiv [International Exam in Fundamentals of Medicine (IFOM) - 2019: expert assessment]. Retrieved from: https://moz.gov.ua/article/news/mizhnarodnijispit-z-osnov-medicini-ifom---2019-ocinka-ekspertiv [in Ukrainian].

6. Miskiv, V.A. (2014). Deiaki aspekty vykladannia anatomii dlia studentiv medychnoho koledzhu. [Some aspects of teaching anatomy for medical college students]. Visnyk problem biolohii i medytsyny - Bulletin of Problems Biology and Medicine, 4, 2 (114), 51-57 [in Ukrainian].

7. Obukhova, Z.O. Vykladannia anatomii liudyny u vyshchii medychnii shkoli: kreatyvnist yak zaporuka yakosti znan [Teaching human anatomy in medical school: creativity as a guarantee of quality knowledge]. Retrieved from: https://vseosvita.ua/library/dopovid-na-zasidannipredmetnoi-ciklovoi-metodicnoi-komisii-prirodniconaukovoi-pidgotovki-na-temu-vikladanna-anatomii-ludiniu-visij-medicnij-skoli-k-180162.html [in Ukrainian].
12. O’Byrne Patrick J. The development of interactive online learning tools for the study of Anatomy / Patrick J. O’Byrne, Anne Patry, Jacqueline A. Carnegie // Medical Teacher. - 2008. - Vol. 30, Issue 8. DOI: $10.1080 / 01421590802232818$.

13. Papa V. Teaching fnatomy in the XXI century: New aspects and pitfalls / V. Papa, M. Vaccarezza // The Scientific World Journal. - November 2013. DOI: $10.1155 / 2013 / 310348$.

14. The large and small circulation. Atlas of human anatomy. - Access mode : http://anthropotomy.com/.

8. Proniaiev, D.V. (2017). Shchodo metodyky vykladannia anatomii u vyshchykh navchalnykh zakladakh [On the methods of teaching anatomy in higher education]. Perspektyvy rozvytku medychnoi nauky i osvity: zbirnyk tez dopovidei Vseukrainskoi naukovo-metodychnoi konferentsii, prysviachenoi 25-richchiu Medychnoho instytutu Sumskoho derzhavnoho universytetu - Prospects for the Development of Medical Science and Education. November 16-17. Sumy: SumDU [in Ukrainian].

9. Sapin, M.R. (2011). Anatomiya cheloveka - bazovaya nauka v medytsynskom obrazovanii [Human anatomy - basic science in medical education]. Medytsynskoe obrazovanye i professyonalnoye razvitiye - Medical Education and Professional Development, 2 (4), 96-97 [in Russian].

10. Cherkasov, V.H. (2011). Suchasna orhanizatsiia pedahohichnoho protsesu na kafedri anatomii liudyny [Modern organization of the pedagogical process at the Department of Human Anatomy]. Naukovyi visnyk Uzhhorodskoho universytetu. Ser.: Medytsyna - Scientific Bulletin of Uzhhorod University. Medicine Series, 2, 365-369. Retrieved from: http://nbuv.gov.ua/UJRN/ UNUMED_2011_2_82 [in Ukrainian].

11. Udochkina, L.A. (2013). Formirovanye kompetentnostnogo podkhoda v izuchenii anatomii cheloveka [Formation of the competence approach in the study of human anatomy]. Medytsynskyi zhurnal Zapadnoho KazakhstanaMedical Journal of Western Kazakhstan, 3 (39), 15-19 [in Russiam].

12. Patrick J. O’Byrne, Anne Patry \& Jacqueline A Carnegie (2008). The development of interactive online learning tools for the study of Anatomy. Medical Teacher, 30 (8). DOI: $10.1080 / 01421590802232818$

13. Papa, V. (2013). Teaching anatomy in the XXI century: New aspects and pitfalls. The Scientific World Journal. DOI: $10.1155 / 2013 / 310348$.

14. The large and small circulation. Atlas of Human Anatomy. Retrieved from: http://anthropotomy.com/. 